\title{
Bacillus amyloliquefaciens-Derived Lipopeptide Biosurfactants Inhibit Biofilm Formation and Expression of Biofilm-Related Genes of Staphylococcus aureus
}

\author{
Karolína Englerová ${ }^{1}$, Zdenka Bedlovičová ${ }^{2, *} \mathbb{D}$, Radomíra Nemcová ${ }^{1}$, Ján Király ${ }^{1} \oplus$, Marián Mad'ar ${ }^{1}$, \\ Vanda Hajdučková $^{1}$, Eva Styková ${ }^{3}\left(\mathbb{D}\right.$, Rastislav Mucha ${ }^{4}{ }^{\circledR}$ and Katarína Reiffová ${ }^{5}$ \\ 1 Department of Microbiology and Immunology, University of Veterinary Medicine and Pharmacy, \\ Komenského 73, 04181 Košice, Slovakia; karolina.englerova@student.uvlf.sk (K.E.); \\ radomira.nemcova@uvlf.sk (R.N.); jan.kiraly@uvlf.sk (J.K.); marian.madar@uvlf.sk (M.M.); \\ vanda.hajduckova@uvlf.sk (V.H.) \\ 2 Department of Chemistry, Biochemistry and Biophysics, University of Veterinary Medicine and Pharmacy, \\ Komenského 73, 04181 Košice, Slovakia \\ 3 Equine Clinic, University of Veterinary Medicine and Pharmacy, Komenského 73, 04181 Košice, Slovakia; \\ eva.stykova@uvlf.sk \\ 4 Institute of Neurobiology BMC, Slovak Academy of Sciences, Šoltésovej 4-6, 04001 Košice, Slovakia; \\ mucha@saske.sk \\ 5 Department of Analytical Chemistry, Institute of Chemistry, Faculty of Science, Pavol Jozef Šafárik University \\ in Košice, Moyzesová 11, 04154 Košice, Slovakia; katarina.reiffova@upjs.sk \\ * Correspondence: zdenka.bedlovicova@uvlf.sk; Tel.: +421-944-21-98-17
}

\section{check for} updates

Citation: Englerová, K.; Bedlovičová, Z.; Nemcová, R.; Király, J.; Mad'ar, M.; Hajdučková, V.; Styková, E.; Mucha, R.; Reiffová, K. Bacillus amyloliquefaciensDerived Lipopeptide Biosurfactants Inhibit Biofilm Formation and Expression of Biofilm-Related Genes of Staphylococcus aureus. Antibiotics 2021, 10, 1252. https://doi.org/ 10.3390/antibiotics10101252

Academic Editor: Wolf-Rainer Abraham

Received: 10 September 2021

Accepted: 13 October 2021

Published: 15 October 2021

Publisher's Note: MDPI stays neutral with regard to jurisdictional claims in published maps and institutional affiliations.

Copyright: (c) 2021 by the authors. Licensee MDPI, Basel, Switzerland. This article is an open access article distributed under the terms and conditions of the Creative Commons Attribution (CC BY) license (https:// creativecommons.org/licenses/by/ $4.0 /)$.
Abstract: Biosurfactants (BSs) are surface-active compounds produced by diverse microorganisms, including the genus Bacillus. These bioactive compounds possess biological activities such as antiadhesive, antimicrobial and antibiofilm effects that can lead to important applications in combating many infections. Based on these findings, we decided to investigate the antibiofilm activity of BSs from the marine Bacillus amyloliquefaciens against Staphylococcus aureus CCM 4223. Expression of biofilm-related genes was also evaluated using qRT-PCR. Isolated and partially purified BSs were identified and characterized by molecular tools and by UHPLC-DAD and MALDI-TOF/MS. Bacillus amyloliquefaciens $3 / 22$, that exhibited surfactant activity evaluated by oil spreading assay, was characterized using the $16 \mathrm{~S}$ rRNA sequencing method. Screening by PCR detected the presence of the $s f p$, srfAA, fenD and ituD genes, suggesting production of the lipopeptides (LPs) surfactin, fengycin and iturin. The above findings were further supported by the results of UHPLC-DAD and MALDI-TOF/MS. As quantified by the crystal violet method, the LPs significantly $(p<0.001)$ reduced biofilm formation of $S$. aureus in a dose-dependent manner and decreased expression of biofilm-related genes $f n b A, f n b B$, sortase $A$ and ica $A D B C$ operon. Data from our investigation indicate a promising therapeutic application for LPs isolated from B. amyloliquefaciens toward prevention of S. aureus biofilm infections.

Keywords: Bacillus amyloliquefaciens; biosurfactant; lipopeptides; Staphylococcus aureus; antibiofilm activity

\section{Introduction}

Antibiotic resistance and nosocomial infections are becoming a major issue in medicines today. Aside from other factors, biofilms contribute to such a situation. Biofilms allow microorganisms to colonize not only tissues and organs but also various medical instruments and equipment and thus significantly contribute to the development and spreading of nosocomial infections. Characteristic features of biofilm-producing microorganisms involve increased resistance against antimicrobials and disinfectants and the ability to resist the immune system of the host. Antibiotic (ATB) therapy of biofilm infections is very demanding and often insufficient and, therefore, these infections may become long-lasting and frequently also regressive [1,2]. 
Staphylococcus aureus is an important opportunistic pathogen with a very variable genome and thus is responsible for a broad spectrum of infections. It belongs to the group of pathogenic microorganisms that are the most frequent agents of communal infections and infections associated with health care [3]. It colonizes mostly the nasal mucosa. These infections are frequently induced by impairment of mucosal barrier and penetration of bacterial cells into the tissues or bloodstream. It is a causative agent of a great number of infections such as acute skin abscesses, bacteraemia, endocarditis and infections of chronic wounds. S. aureus infections are complicated and difficult to eradicate, particularly those caused by a methicillin-resistant strain (MRSA) [4]. S. aureus belongs among the most common agents of chronic infections associated with biofilm formation. Production of biofilm by these bacteria was most frequently observed on medical implants and host tissues [5]. In the food industry, S. aureus biofilm on food contact surfaces poses serious risks of food contamination that cause staphylococcal gastroenteritis in humans [6].

There have been efforts worldwide to look for new approaches or targeted strategies for the discovery of novel antibacterial therapies not associated with the risk of inducing resistance. These include, for example, traditional medicine, enhanced immune stimulation, vaccines, engineered bacteriophages, probiotics, prebiotics and biosurfactants [7-9]. Another area of enormous potential is the development of antimicrobial and antibiofilm peptides, also known as host defense peptides (HDPs). These peptides can exert direct antibacterial effects by targeting planktonic cells and exhibit antibiofilm, antiviral, antifungal and host-directed immunomodulatory activities. They are believed to act on multiple targets, thereby possibly lowering the rate of evolution of resistance mechanisms $[10,11]$.

Biosurfactants (BSs) are natural products of several bacterial species defined as surfaceactive compounds able to reduce the surface and interfacial tension of liquids, solids and gases, allowing these components to be easily mixed or dispersed in the form of emulsions in water or other fluids [12]. BSs are also useful as antibacterial, antifungal, antiviral compounds because they show anti-adhesive activity and cause biofilms to disintegrate [13]. These bioactive compounds possess several advantages when compared to synthetic surfactants, such as low toxicity and irritability, high biodegradability, bioavailability and digestibility, biocompatibility and stability in a wide range of $\mathrm{pH}$, temperature and salinity [14]. Due to these interesting features, they have been extensively used in different fields, such as the food, cosmetics, pharmaceutical or agricultural industries [15]. Rhamnolipids, mannosyl-erythritol lipids and sophorolipids have been used in cosmetic applications in several different formulations, for example, anti-aging skin care products, shower gel, moisturizing skin cleanser, shampoo, and toothpastes [16]. Rhamnolipids and surfactins produced by Pseudomonas sp., Bacillus sp. and Acinetobacter sp. are useful in the removal of polyaromatic hydrocarbons, pentachlorophenol and heavy metals from soil. In addition, rhamnolipids and fengycins have shown potential as biopesticides, fungicides and antizoospore agents [17]. In the food industry, microbial BSs are used in the treatment/cleaning of surfaces coming into contact with food, and as food additives/ingredients. For example, Saccharomyces cerevisiae produces a mannoprotein capable of stabilizing water/oil emulsions in biscuits, mayonnaise and ice cream. Lipopeptide bioemulsifier produced by $B$. subtilis significantly improves the texture profile of bread and reduces the sensitivity to microbial proliferation [18]. In the medical field, biosurfactants are not only useful as antibacterial, antifungal, antiviral and anti-adhesive agents (pumilacidin, treahalose lipid, lichenysin, surfactin) but also have a potential for use as major immunomodulatory molecules (mannosylerythritol lipids) and even for anticancer treatment (surfactin, fengycin) and gene therapy (mannosylerythritol lipids) as well as an adjuvant in vaccines (iturin) [19].

Representatives of the genus Bacillus, commonly found in marine environments, produce a wide spectrum of antimicrobial and fungicidal compounds [20]. For example, B. subtilis, B. amyloliquefaciens, and Bacillus atrophaeus have the potential to produce secondary metabolites, especially cyclic lipopeptides (LPs) that belong to the family of biosurfactants, which make them useful for agricultural, pharmaceutical and biotechnological 
applications [21]. These lipopeptide metabolites are divided into three families, surfactins, iturins and fengycins [22], which differ one from another by the length and branching of the fatty acid side chains and by the amino acid substitutions in the peptide ring [23]. Surfactin produced by B. subtilis was the first known BS and was isolated by Arima et al. [24]. The exact structure was established by Kakinuma et al. [25]; surfactin is a cyclic LP with a $\beta$-hydroxy fatty acid as the hydrophobic moiety linked to a specific sequence of seven $\alpha$-amino acids, L-Glu-L-Leu-L-Leu-L-Val-L-Asp-L-Leu-L-Leu, by an amide group and a lactone bond [26]. Iturin is a cyclic peptide of seven amino acids (heptapeptides) linked to a fatty acid ( $\beta$-amino) chain [23], while fengycin is a cyclic decapeptide with a $\beta$-hydroxy fatty acid in its side chain [27]. In the context of biological control of diseases, these LPs are widely considered as potential alternatives to the growing problem of resistance to conventional antibiotics, fungal infections, and life-threatening diseases [28].

The aim of the study was to isolate BSs from the marine Bacillus amyloliquefaciens $3 / 22$ and test their antibiofilm activity against biofilm-producing reference strain Staphylococcus aureus CCM 4223 under in vitro conditions. Isolated and partially purified LPs were identified and characterized by molecular tools and by UHPLC-DAD (ultrahigh-performance liquid chromatography with diode array detector) and MALDI-TOF/MS (matrix-assisted laser desorption/ionization time-of-flight/molecular mass). Expression of biofilm-related genes was also evaluated.

\section{Results}

\subsection{Genotypic Identification of the Isolate}

The 16S rRNA sequencing result indicated that the marine isolate belonged to the Bacillus genus. BLASTn (basic local alignment search tool nucleotide) analysis (Table 1) showed 100\% similarity with B. amyloliquefaciens. The sequence was deposited in GenBank and subsequently approved and published with the accession number MN435585.

Table 1. Results of BLASTn analysis of $16 \mathrm{~S}$ rRNA and BS genes of B. amyloliquefaciens 3/22.

\begin{tabular}{cc}
\hline Gene & GenBank Sequence Identity/Accession Number \\
\hline 16 rRNA & B. amyloliquefaciens $(100 \%)$ \\
SrfAA & KF811045.1 \\
sfp & KC. subtilis $(97.95 \%)$ \\
$f e n B$ & B. amyloliquefaciens $(99.56 \%)$ \\
$f e n D$ & KX346253.1 \\
NA & B. amyloliquefaciens $(96.63 \%)$ \\
ituD & KP453873.1 \\
& B. amyloliquefaciens $(99.36 \%)$ \\
\end{tabular}

NA—no fragment amplification was observed.

\subsection{Presence of Surfactin, Fengycin and Iturin A Genes}

PCR (polymerase chain reaction) assays followed by sequencing were conducted to investigate the occurrence of genes for the production of surfactin transcriptional terminator $(s f p)$, surfactin synthase subunit $1(\operatorname{srf} A A)$, fengycin synthetase $(f e n B, f e n D)$ and malonyl CoA transacylase $(i t u D)$; the selected $s f p$ gene primers amplifieda 675 bp product. Of similar intensity was the detected $201 \mathrm{bp}$ product of amplification of the srfAA gene. Selected primers of $f e n B$ gene failed to amplify the product of size $670 \mathrm{bp}$. On the contrary, we detected product of the gene $f e n D(269 \mathrm{bp})$ as well as the gene ituD (482 bp). The intensity of amplification products of fragments of genes $f e n D$ and it $u D$ detected in the tested strain was higher in comparison to that of fragments of genes sfp and srfAA.

BLASTn analysis (Table 1) showed that the $\operatorname{srfAA}$, sfp and ituD genes were detected in B. amyloliquefaciens $3 / 22$ with $97-99 \%$ identity. A somewhat lower percentage of identity 
was observed for the $f e n D$ gene. The sequence of genes found in this isolate were submitted to GenBank and published under the following accession numbers: MK328493 (srfAA), MK328487 (sfp), MK328481 (fenD), MK328484 (ituD).

\subsection{Ultrahigh-Performance Liquid Chromatography}

The UHPLC method with DAD detector was used for the immediate detection of studied lipopeptides. The chromatograms of standards-fengycin, iturin A, and surfactin are presented in Figure 1 (up). The flow rate, mobile phases ratio and injection volumes were varied to find out the method for good separation of studied matrices. The mobile phase consisted of $0.025 \%$ trifluoroacetic acid (TFA) in acetonitrile (eluent A) and water (eluent B). As the chromatograms of the mentioned standard lipopeptides show, we observed three main groups of peaks. The iturin A standard retention time was detected in the range of $11.25-22.5 \mathrm{~min}$. Then we attributed the peaks for fengycin standard at $35.0-45.0 \mathrm{~min}$. Finally, the three surfactin standard peaks were eluted at $15.73,18.46$ and $20.90 \mathrm{~min}$, connected with a broad group of peaks in the scale of 51.0-60.0 min [29]. As can be seen in Figure 1 (down), the UHPLC chromatogram of the studied isolates of B. amyloliquefaciens 3/22 LPs contained the peaks of mentioned lipopeptides isomers attributed by comparing the retention times. The retention times for iturin $\mathrm{A}$ isomers presented in the studied isolate of B. amyloliquefaciens 3/22, were 11.77, 12.38, 13.13, 14.39, $15.01,15.89,16.13$, and $16.68 \mathrm{~min}$. The retention times for surfactin isomers were observed at $15.61,18.50,22.19,51.44,53.94,54.54,54.64,55.90,56.10$, and $56.26 \mathrm{~min}$. The fengycin isomers were eluted at 36.40, 37.23, 38.34, 39.28, 40.11, 40.71, 41.04, and $42.30 \mathrm{~min}$. This confirmed the results of the genetic analysis mentioned in this article.

\subsection{MALDI-TOF/MS Analysis}

The lyophilized extract of LPs from B. amyloliquefaciens 3/22 was subjected to MALDITOF/MS analysis as an acetonitrile solution. In the spectra of isolated LP, peaks with masses very similar to LP compounds were detected. As shown in Figure 2, the most intensive signals in the $m / z$ range of 1400-1600 were observed in the MALDI-TOF/MS spectra of the isolated lipopeptide mixture. The peak at $m / z=887.9$ was attributed to iturin $\mathrm{A}$, the peaks at $m / z=1029$ and 1044 were attributed to surfactin and the ions between $m / z=1400-1600$ were regarded as belonging to fengycin $(1479.7,1465.5,1451.5$, 1437.1, 1423). Results obtained by MALDI-TOF/MS and HPLC methods confirmed that B. amyloliquefaciens $3 / 22$ produces surfactin, fengycin and iturin $A$, the three families of lipopeptide biosurfactants.

\subsection{The Effect of LPs 3/22 on S. aureus CCM 4223 Biofilm Formation}

Antimicrobial activity of LPs $3 / 22$ against S. aureus in planktonic cells was determined by MIC (minimal inhibitory concentration). The results showed that MIC value was $15 \mathrm{mg} / \mathrm{mL}$. Inhibition of biofilm formation by LPs 3/22 was compared with the control by analyzing absorbance of crystal violet. As shown in Figure 3, the LPs produced by B. amyloliquefaciens $3 / 22$ significantly $(p<0.001)$ reduced biofilm formation by $S$. aureus CCM 4223 in a dose-dependent manner. The biofilm formation by the indicator strain was completely inhibited when concentration of LPs $3 / 22$ reached $15 \mathrm{mg} / \mathrm{mL}$. Concentrations of LPs $3 / 22$ equal to 1.5 and $0.15 \mathrm{mg} / \mathrm{mL}$ inhibited the formation of biofilm by more than $50 \%$. The percentage of inhibition of biofilm formation lower than $50 \%$ was observed at concentrations of LPs $0.015 \mathrm{mg} / \mathrm{mL}$ (Table 2). 

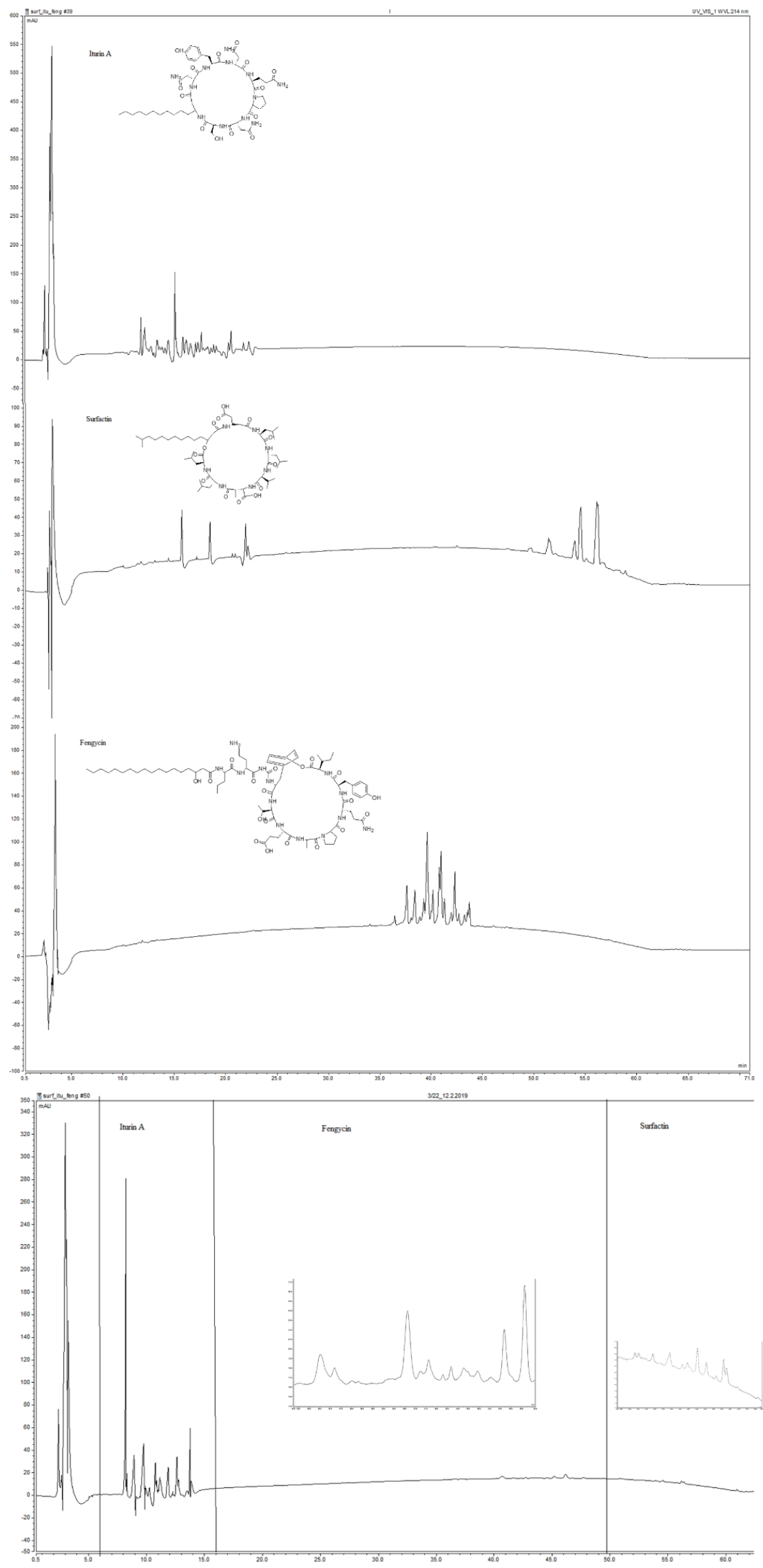

Figure 1. Chromatogram of standards (up) and LPs from B. amyloliquefaciens $3 / 22$ (down), containing components of iturin A, surfactin and fengycin. 


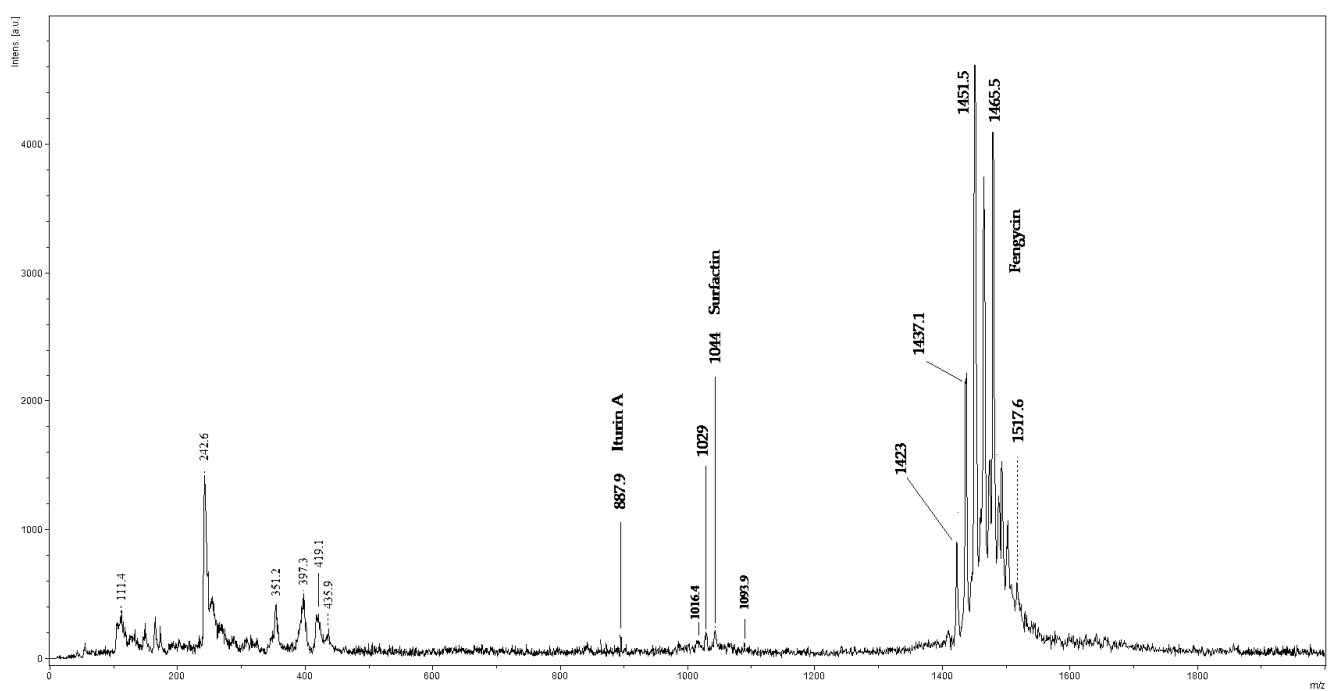

Figure 2. MALDI-TOF/MS Spectra of LPs Isolated from B. amyloliquefaciens 3/22.

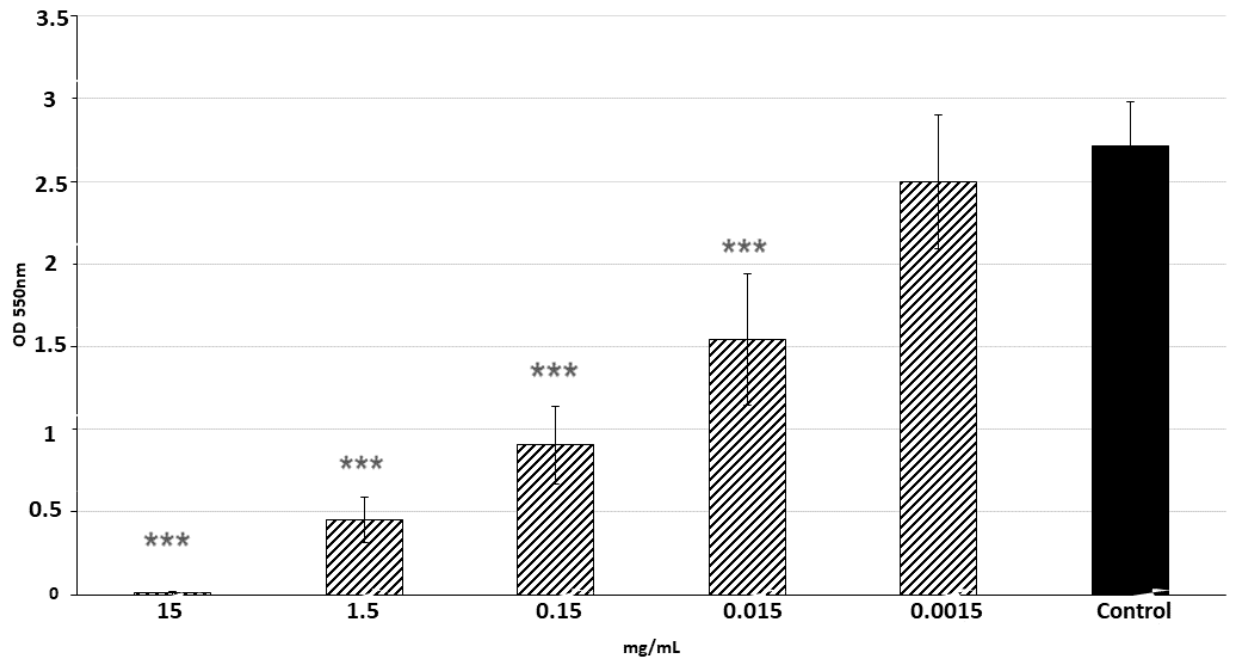

Figure 3. The effect of LPs $3 / 22$ on S. aureus CCM 4223 biofilm formation. Control-S. aureus CCM 4223 in $\mathrm{mBHI}$ broth (brain heart infusion) without LPs 3/22; data are presented as the means \pm standard deviation; ${ }^{* * *}(p<0.001)$ - significant difference compared to the non-treated control.

Table 2. The percentage of inhibition of biofilm formation by S. aureus CCM 4223.

\begin{tabular}{ccccc}
\hline \multirow{2}{*}{ Activity [\%] } & \multicolumn{4}{c}{ Concentration of LPs 3/22 [mg/mL] } \\
\cline { 2 - 5 } & $\mathbf{1 5}$ & $\mathbf{1 . 5}$ & $\mathbf{0 . 1 5}$ & $\mathbf{0 . 0 1 5}$ \\
\hline Inhibition of biofilm formation & $100.19 \pm 4.14$ & $84.46 \pm 4.21$ & $60.09 \pm 2.06$ & $38.84 \pm 13.76$ \\
\hline
\end{tabular}

\subsection{Analysis of qRT-PCR Results}

We conducted qRT-PCR (quantitative real-time polymerase chain reaction) using primers described elsewhere to determine whether expression of biofilm-related genes in $S$. aureus biofilms was regulated by subinhibitory $(1.5 ; 0.15 ; 0.015 \mathrm{mg} / \mathrm{mL})$ concentrations of LPs 3/22. Figure 4 shows that LPs produced by B. amyloliquefaciens 3/22 modulated the expression of biofilm-related genes in $S$. aureus CCM 4223. The results of measuring the expression level of $f n b A$ and $f n b B$ genes indicated a significant 14.37- and 29.56-fold downregulation when the culture media were supplemented with $1.5 \mathrm{mg} / \mathrm{mL}$ of LPs $3 / 22$ and 22.94- and 13.67-fold down-regulation when they were supplemented with $0.15 \mathrm{mg} / \mathrm{mL}$ of LPs 3/22. The expression level of $f n b A$ gene was significantly decreased (1.3-fold) also 
at the LPs $3 / 22$ concentration of $0.015 \mathrm{mg} / \mathrm{mL}$. Transcription levels of sortase $A$ gene in biofilms that were treated with $1.5 \mathrm{mg} / \mathrm{mL}$ and $0.15 \mathrm{mg} / \mathrm{mL}$ of LPs $3 / 22$ decreased by 1.86- and 1.72-fold, respectively, compared with the non-treated control. As observed from the results, icaA gene was significantly down-regulated by 2.82-, 5.5- and 1.17-fold when the culture media were supplemented with $1.5 \mathrm{mg} / \mathrm{mL}, 0.15 \mathrm{mg} / \mathrm{mL}$ and $0.015 \mathrm{mg} / \mathrm{mL}$ of LPs 3/22, respectively. Similarly, at the LPs $3 / 22$ concentration of $1.5 \mathrm{mg} / \mathrm{mL}$ the genes icaD, icaB and icaC were inhibited by 1.85-, 2.25- and 2.37-fold, respectively, and at the LPs $3 / 22$ concentration of $1.5 \mathrm{mg} / \mathrm{mL}$ by $3.72-2.98-$ and $6.99-$ fold, respectively. The expression level of agrA gene was significantly decreased by 1.42 -fold at the LPs $3 / 22$ concentration of $0.15 \mathrm{mg} / \mathrm{mL}$ compared with the non-treated control.
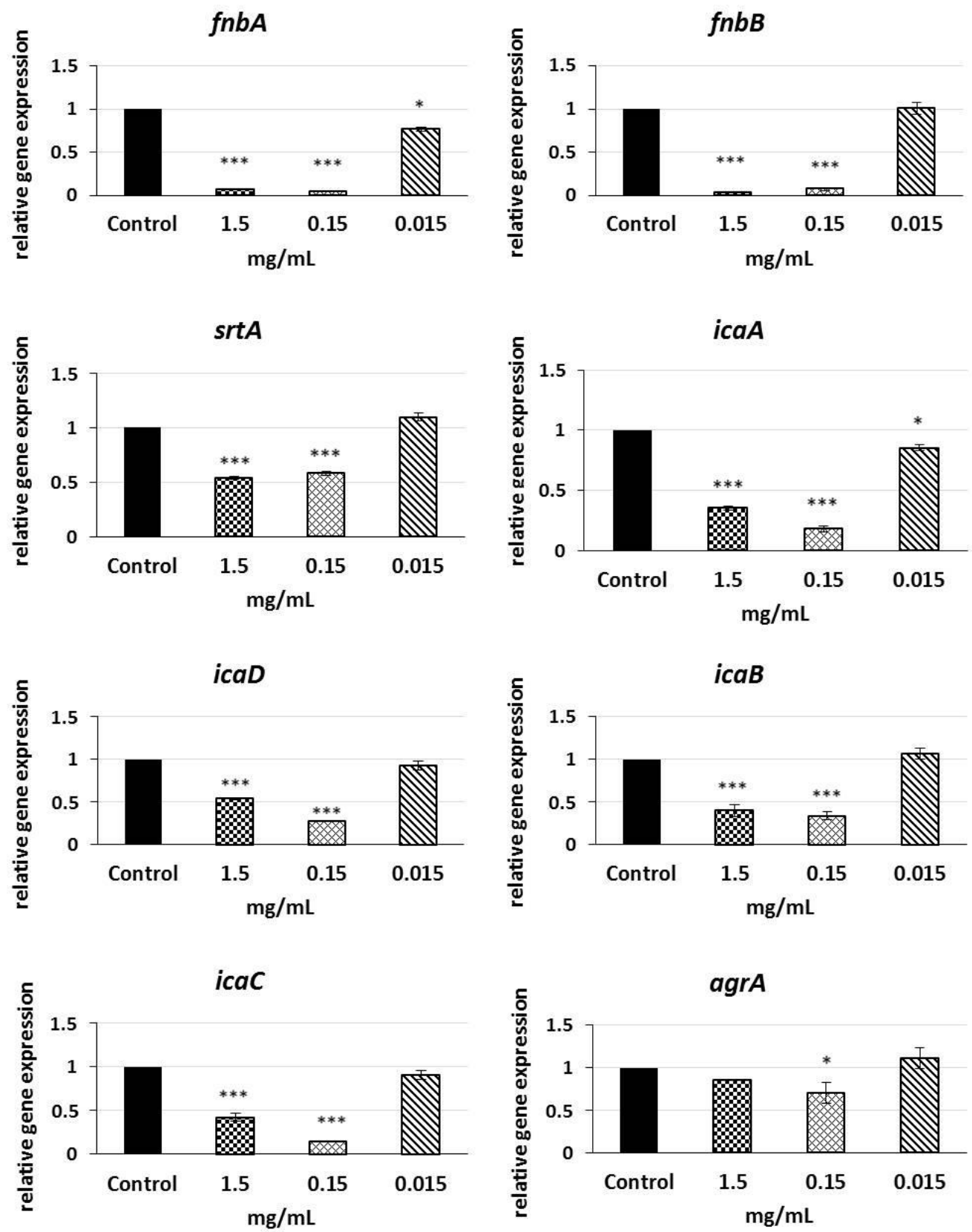

Figure 4. The effect of LPs $3 / 22$ on mRNA (messenger RNA) decreased expression of biofilm-related genes in S. aureus CCM 4223; data are presented as means \pm standard deviation; ${ }^{*}(p<0.05)$ and *** $(p<0.001)$ - significant difference compared to the non-treated control. 


\section{Discussion}

In the present study, BSs produced by marine strain B. amyloliquefaciens $3 / 22$ were characterized and evaluated for their antibiofilm activity in vitro. PCR analysis revealed that this strain possessed the genes coding for the simultaneous co-production of 3 LPs: surfactin $(s f p, s r f A A)$, fengycin $(f e n D)$ and iturin $(i t u D)$. Several authors also detected the presence of genes encoding the co-production of three or more LPs by Bacillus spp. Plaza et al. [30] demonstrated the co-production of iturin $(i t u C$, ituD), fengycin $(f e n B$, fenD and surfactin (srfAA) by three strains of Bacillus subtilis KP7, T'-1 and I'-1a. Zhang et al. [31] found LP genes (fenB, $s f p$, and $i t u D)$ in B. amyloliquefaciens W10 isolated from tomato rhizosphere. Xu et al. [32] first identified cyclic lipopeptides from Bacillus siamensis. The results of these authors showed that PCR products of $s f p$, srfD, fenB, ituA, and ituC were amplified. He et al. [33] reported the presence of the LP genes $s f p$ (surfactin), fen $B$ (fengycin), ituD (iturin) in B. subtilis Czk1, which was obtained from the aerial roots of rubber trees. It was contemplated that the co-production of several LPs by one strain can increase their synergistic effect [34]. Iturin A and fengycin separately exhibited antifungal activity. Surfactin exhibits antibacterial properties and acts in a synergistic mode through enhancing the antifungal activity of iturin A [35]. Genes responsible for the production of LPs were detected also in other representatives of the genus Bacillus. The strain B. subtilis Bbv 57 was positive for iturin (ituD gene) and surfactin (srfA gene; sfp gene) lipopeptides [36]. Co-production of iturin and surfactin by additional Bacillus spp. was also described. The strains Bacillus cereus UASBR3, B. cereus UASBR6, B. subtilis UASBR5, B. pumilus UASBR8, and $B$. amyloliquefaciens UASBR9 have been known to possess the srfAA and ituC genes [37]. The presence of genes encoding ituD and $s f p$ were detected in Bacillus sp. P5 isolated from puba (food made by spontaneous fermentation of cassava roots), suggesting the production of iturin A and surfactin by this strain [38]. In another study, the presence of the srfAA gene was detected in 15 strains of B. subtilis, B. pumilus, Bacillus megaterium and B. amyloliquefaciens isolated from potato rhizosphere in Iran. In addition, the fenD gene was detected in $80 \%$ and $i t u C$ in $66.7 \%$ of the tested strains [39]. Co-production of fengycin (fenB) and iturin (ituA) was detected in B. subtilis YB-05 [40]. Similarly, PCR detection showed that $B$. amyloliquefaciens PG12 isolated from apple fruit possessed the genes $i t u D$, ituC, fenB, $f e n C$ and $f e n F$, which are responsible for the production of fengycin and iturin [41].

Lipopeptides isolated from B. amyloliquefaciens $3 / 22$ strain were identified by UHPLCDAD and MALDI-TOF/MS analysis. The LC methods are standardly used for the biosurfactants characterization [41-43]. The example of a three-stage strategy using the gradient elution was published by Yang [40]. As eluent authors used the acetonitrile-water mixture in various ratios at the flow rate of $0.8 \mathrm{~mL} / \mathrm{min}$. The analysis time was $25 \mathrm{~min}$. Under the mentioned conditions, our separation process of LPs failed, so we changed the eluent by adding trifluoroacetic acid (TFA) [43]. Better separation was observed by the addition of $0.025 \%$ TFA into acetonitrile and water. Finally, we identified iturin A, fengycin and surfactin LPs at $11-17 \mathrm{~min}, 36-43 \mathrm{~min}$, and $51-57 \mathrm{~min}$, respectively. In summary, we can confirm that under the changed conditions of elution, we were able to separate the studied lipopeptide biosurfactants of $3 / 22$. The MALDI-TOF/MS analysis is a broadly used methodology for lipopeptides identification. This method is sensitive and reveals the ion sequences of cyclic peptides [40]. For the $3 / 22$ LPs identification, we noticed ions at $m / z=1093.9$ (iturin A), 1016.4, 1029 and 1044 (surfactin) and 1465.5 (fengycin). These observations are in good agreement with the literature, for example, the study of the B. subtilis CMB32 strain by Kim et al. [44], in which the authors identified peaks in the range of 1016 and 1044 for surfactin, fengycin was observed at $m / z 1452$ and 1542, and between 1066 and 1094 iturin peaks were detected. A comparable mass intensity was found in another study by Bernat et al. [45].

BSs are very attractive natural molecules with antimicrobial and antibiofilm properties due to their amphiphilic nature [46]. The antimicrobial action of BSs involves their ability to disrupt membrane integrity, leading to cell lysis and metabolite leakage. Moreover, changes in the membrane structure and impairment of proteins conformations alter the 
essential membrane functions including production and transport of energy [47,48]. In addition to antimicrobial action, the antibiofilm activity of BSs is associated also with their ability to affect adhesion and dislodgement of bacteria from the surface due to the changes in surface tension and bacterial cell-wall charge [49] and their influence on expression of biofilm-related genes [50,51].

Despite the advances made in studying the $S$. aureus biofilm formation, its architecture and role in pathogenesis and drug resistance [52], less is known about the mechanism of action of LPs in inhibiting this biofilm. The results of experiments carried out during coincubation (effect on biofilm formation and pre-formed biofilms) or pre-coating (preventing microbial adhesion) indicate the antibiofilm action of LPs against potential pathogens including $S$. aureus.

Giri et al. [53] evaluated the anti-adhesive activities of the LPs from B. subtilis VSG4 and B. licheniformis VS16 against S. aureus ATCC 29523, Salmonella typhimurium ATCC 19430, and Bacillus cereus ATCC 11778. The pre-coating assays showed that the LPs exhibited anti-adhesive activity, even at concentrations of $3-5 \mathrm{mg} / \mathrm{mL}$ and caused the biofilm eradication with percentages ranging from 63.9 to $80.03 \%$ for VSG4 biosurfactant, and from 61.1 to $68.4 \%$ for VS16 biosurfactant. Janek et al. [54] reported the ability of the cyclic lipopeptide pseudofactin II $(0.5 \mathrm{mg} / \mathrm{mL})$ to prevent formation of biofilm by Escherichia coli, Enterococcus faecalis, Enterococcus hirae, Staphylococcus epidermidis, Proteus mirabilis and Candida albicans on a polystyrene surface. De Araujo et al. [55] observed that surfactin at $0.50 \%(w / v)$ significantly reduced adhesion of Listeria monocytogenes to a polystyrene surface and at higher concentrations achieved as high as $54 \%$ inhibition. In another study by Abdelli et al. [47] it was observed that surfactin obtained by Bacillus safensis F4, at concentrations of 5 and $10 \mathrm{mg} / \mathrm{mL}$, exhibited anti-adhesive activity against the biofilm forming by $S$. epidermidis S61, which exceeded $80 \%$. Rivardo et al. [56] demonstrated specific anti-adhesion activity of two biosurfactants from B. subtilis and B. licheniformis. The V9T14 biosurfactant inhibiting biofilm adhesion of E. coli CFT073 was ineffective against the S. aureus ATCC 29213 biofilm and, on the contrary, the V19T21 biosurfactant inhibited adhesion of S. aureus ATCC 29213 but was ineffective against E. coli CFT073. Biofilm formation by E. coli and S. aureus was decreased by $97 \%$ and $90 \%$, respectively. The antiadhesive activity against biofilm of both strains was attributed to the fraction belonging to the fengycin-like family obtained by flash chromatography from each purified biosurfactant. Cordeiro et al. [57] observed that the co-incubation of the B. subtilis biosurfactant TIM96 (mixture of surfactin, iturin and fengycin) with clinical strains of Trichosporon reduced adhesion of fungal cells by up to $96.89 \%$ and caused up to a $99.2 \%$ reduction in the metabolic activity of mature Trichosporon biofilms, decreasing their thickness and cell viability. A complex of surfactants PPE (polymyxin D1, fusaricidin B and traces of surfactin) isolated from Paenibacillus polymyxa at a concentration of $2 \mathrm{mg} / \mathrm{mL}$, inhibited (87-98\%) formation of many Gram positive bacterial biofilms including those produced by S. aureus [58]. Surfactin isolated from B. amyloliquefaciens NS6 exhibited dispersion activity against the biofilm of Streptococcus mutans, when, at the highest concentration of $80 \mathrm{mg} / \mathrm{mL}$ the dispersion reached 62\% [59]. Meena et al. [60] reported that biofilms of pathogenic bacterial strains S. aureus ATCC 6538, Pseudomonas sp., Klebsiella pneumoniae, E. coli NCTC 10418, Salmonella typhi and S. typhimurium NCTC74, treated with surfactin isolated from B. subtilis KLP2015 (100 $\mu \mathrm{g} / \mathrm{mL})$, were reduced by $58.10 \%, 47.86 \%, 14.83 \%$, $13.91 \%, 11.01 \%$ and $10.23 \%$, respectively.

Results of the present study showed that the co-incubation of the mixture of surfactin, fengycin and iturin from B. amyloliquefaciens $3 / 22$ with S. aureus CCM 4223 significantly inhibited biofilm formation in a dose-dependent manner. The percentage of inhibition of biofilm formation at concentrations of 15, 1.5, 0.15 and $0.015 \mathrm{mg} / \mathrm{mL}$ ranged from 100 to $39 \%$. Antimicrobial activity of LPs $3 / 22$ has been tested preliminary in an antimicrobial assay. MIC value was $15 \mathrm{mg} / \mathrm{mL}$. This means that the concentrations 1.5, 0.15 and $0.015 \mathrm{mg} / \mathrm{mL}$ had no inhibitory effect on the growth of the indicator strain. Our previous investigations under the pre-coating conditions showed that LPs $3 / 22$ significantly affected 
S. aureus CCM 4223 adhesion to a polystyrene microplate $(p<0.01 ; p<0.05)$ and strongly promoted the biofilm dislodging [61].

Another part of our study was devoted to the analysis of expression of biofilm-related $f n b A, f n b B, s r t A, i c a A D B C$ and agr $A$ genes by means of qRT-PCR in order to investigate the potential mechanisms that could form the basis of the observed reduced growth of biofilm in the presence of LPs 3/22. All the investigated genes were involved in the regulation of biofilm formation by $S$. aureus. To the best of our knowledge, no reports are available on the abilities of B. amyloliquefaciens LPs as regulators of S. aureus biofilm-related genes.

The sortaseA enzyme is responsible for covalent anchoring of surface adhesive proteins in the cell wall biosynthesis and thus the excessive expression of the srt $A$ gene contributes to the virulence of S. aureus [62]. The most important adhesins that facilitate attachment of bacterial cells to the biotic surface during the first stage of adhesion include fibronectin binding proteins A and B (FnBPA, FnBPB) [63]. Due to their important influence on the virulence of bacteria, the sortaseA transpeptidase and fibronectin binding proteins constitute a potential target of the development of vaccines and therapeutic strategies $[64,65]$. Our study showed that LPs $3 / 22$ exhibiting a strong negative influence on biofilm formation, significantly $(p<0.001)$ reduced expression of genes $f n b A$ and $f n b B$ and, at the same time, decreased expression of the gene encoding enzyme sortaseA. It has been established that inhibition of the enzyme sortaseA and fibronectin binding proteins brings about impaired development of biofilm which is manifested by its reduced accumulation [66,67].

S. aureus produces polysaccharides of intercellular adhesion (PIA), the release of which is controlled by operon icaADBC. Ica operon participates in regulation of the release of autoinducer-2 signaling molecules in $S$. aureus, by means of which bacteria can sense population density (quorum sensing). These molecules play an important role in intraspecies and interspecies communication [68]. Inhibition of PIA production results in biofilm reduction mediated by genetic regulation of $i c a$ operon genes $[69,70]$. The accessory gene regulator $(a g r)$ is also associated with quorum sensing. The agrB and $\operatorname{agrD}$ genes regulate expression and transport of the autoinducing peptide. As soon as a sufficient amount of the autoinducing peptide aggregates in the surrounding extracellular environment, a two-component system agr $A$ and agrD triggers intracellular communication and sensing of the population density [71]. Our results showed that LPs $3 / 22$ at sub-inhibition concentrations significantly down-regulated $(p<0.001)$ the icaADBC genes expression. AgrA gene expression level was significantly affected $(p<0.05)$ when the concentration of LPs $3 / 22$ reached $0.15 \mathrm{mg} / \mathrm{mL}$. Similar significant down-regulation of expression of $i c a A$ and icaD, as well as alteration of the quorum sensing system by the regulation of the auto inducer 2 was observed by Liu et al. [72] after treatment of S. aureus biofilm with surfactin from B. subtilis. Cramton et al. [73] observed that deletion of ica locus significantly decreased formation of biofilm by $S$. aureus.

\section{Materials and Methods}

\subsection{Microorganisms}

The Bacillus amyloliquefaciens 3/22 strain was isolated from the seaweed sample of the Adriatic Sea and identified using the $16 \mathrm{~S}$ rRNA sequencing method as described below. The indicator strain Staphylococcus aureus CCM 4223 was obtained from the Czech Collection of Microorganisms (Brno, Czech Republic). S. aureus was cultivated in brain heart infusion broth (HiMedia Laboratories, Mumbai, India) with $1 \%$ glucose and $2 \% \mathrm{NaCl}(\mathrm{mBHI}$ broth) for biofilm production. The reference surfactin-producing strain Bacillus subtilis subsp. subtilis DSM 3257 was obtained from Leibniz Institute DSMZ-German Collection of Microorganisms and Cell Cultures.

\subsection{Isolation and Screening of Isolates for BSs Production}

A 0.5 g seaweed sample was homogenized (Stomacher Lab Blender 80, Seward Medical Limited, London, UK) with $4.5 \mathrm{~mL}$ of a sterile diluent. A series of 10 -fold dilutions was 
prepared in an isotonic saline solution. From the appropriate dilutions, $0.1 \mathrm{~mL}$ aliquots were spread onto brain heart infusion agar (BHI agar $\mathrm{pH} 7$; HiMedia) and the plates were incubated at $27^{\circ} \mathrm{C}$ for $48 \mathrm{~h}$ under aerobic conditions. Using the Gram and Wirtz-Conklin staining methods, preparations were made from the pure colonies, and the microscopic images - shape, color, size, arrangement and the presence of spores-were observed and evaluated. Gram-positive, spore-forming, rod-shaped isolates were tested for BSs production. BHI broth (HiMedia) was used as a seed medium, which was inoculated with a loop-full of the previously obtained isolates on BHI agar and incubated at $27^{\circ} \mathrm{C}$ for $18 \mathrm{~h}$. Subsequently, a liquid McKeen medium [74] (20 g/L glucose, $5 \mathrm{~g} / \mathrm{L}$ glutamic acid, $1 \mathrm{~g} / \mathrm{L}$ $\mathrm{K}_{2} \mathrm{HPO}_{4}, 1.02 \mathrm{~g} / \mathrm{L} \mathrm{MgSO}_{4}, 0.5 \mathrm{~g} / \mathrm{L} \mathrm{KCl}, \mathrm{pH}$ 7.0) supplemented with $1 \mathrm{~mL}$ of mineral solution $\left(0.5 \mathrm{~g} / \mathrm{L} \mathrm{MnSO}_{4} \cdot 7 \mathrm{H}_{2} \mathrm{O}, 0.16 \mathrm{~g} / \mathrm{L} \mathrm{CuSO}_{4} \cdot 5 \mathrm{H}_{2} \mathrm{O}, 0.015 \mathrm{~g} / \mathrm{L} \mathrm{FeSO}_{4} \cdot 7 \mathrm{H}_{2} \mathrm{O}\right)$ was inoculated with $2 \%(v / v)$ seed media. After inoculation, the flasks were incubated on a water bath shaker (JULABO SW 2C, Labor Technic GMBH Selbach, Germany) at $27^{\circ} \mathrm{C}$ and $120 \mathrm{rpm}$ for $72 \mathrm{~h}$. The cell-free supernatants (CFS) obtained by centrifugation $\left(4754 \times \mathrm{g} / 45 \mathrm{~min} / 4^{\circ} \mathrm{C}\right)$ were screened for BSs production by an oil spreading test. This test was performed according to Morikawa et al. [75] with the following modification: $20 \mu \mathrm{L}$ of crude oil (Slovnaft, Vlčie hrdlo, Slovakia) was added to the surface of $10 \mathrm{~mL}$ of distilled water in a $60 \mathrm{~mm}$ diameter Petri dish to form a thin oil layer. Then, $100 \mu \mathrm{L}$ of CFS was gently applied to the centre of the oil layer. In a positive case, the oil was displaced, and a clearing zone was formed. The diameter of this clearing zone on the oil surface correlated with the surfactant activity (oil displacement). The reference surfactin-producing strain B. subtilis subsp. subtilis DSM 3257 was used as a positive control, and McKeen medium served as a negative control. The $3 / 22$ isolate that produced the largest clearing zone was selected for further study.

\subsection{Genotypic Identification}

DNAzol Direct (Molecular Research Center Inc., Cincinnati, OH, USA) was used for DNA isolation according to the manufacturer's instructions. A $1 \mu \mathrm{L}$ volume of DNA sample was added to One Taq $2 \times$ Master Mix (New England BioLabs, Ipswich, MA, USA) in a total volume of $50 \mu \mathrm{L}$ and amplified by the PCR method to detect $16 \mathrm{~S}$ ribosomal RNA (rRNA) genes using the following universal primers: Bac27F (5-AGAGTTTGATCMTGGCTCAG-3) and 1492R (5-CGGYTACCTTGTTACGACTT-3) synthesized by Merck-Sigma Aldrich company (Darmstadt, Germany). The expected size of the PCR fragment was 1465 bp [76]. The amplification programme consisted of the following cycle conditions: initial activation for $5 \mathrm{~min}$ at $94{ }^{\circ} \mathrm{C}$; 31 cycles of $1 \mathrm{~min}$ at $94{ }^{\circ} \mathrm{C}$; annealing for $1 \mathrm{~min}$ at $55^{\circ} \mathrm{C}$; extension step of 3 min at $72{ }^{\circ} \mathrm{C}$; final 10 min extension step at $72{ }^{\circ} \mathrm{C}$. The PCR was performed on a thermocycler (TProfessional Basic, Biometra $\mathrm{GmbH}$, Göttingen, Germany). A $10 \mu \mathrm{L}$ aliquot of the product was mixed with $2 \mu \mathrm{L}$ of the mixture composed of $1667 \mu \mathrm{L}$ of $6 \times$ DNA loading buffer (Thermo Fisher Scientific, catalogue number: R0611) and $2 \mu \mathrm{L}$ of 10,000× GelRed ${ }^{\mathrm{TM}}$ dye (Biotium Inc., Hayward, CA, USA). The PCR product was then separated by horizontal 1\% agarose gel electrophoresis in Tris-borate-EDTA buffer $(\mathrm{pH} \mathrm{7.8)}$ and visualized under UV light. The amplification product was purified, and DNA sequencing was performed with Microsynth AG (Balgach, Switzerland). The obtained forward and reverse reads were validated and assembled using Geneious 4.8.5. Software (Biomatters, San Diego, CA, USA). The species was identified based on the consensus sequence of the 16S rRNA gene and by genotyping using online BLASTn analysis (https:/ / BLAST.ncbi. nlm.nih.gov /BLAST.cgi, accessed on 16 September 2019). The validated sequence was sent to GenBank, and the accession number of B. amyloliquefaciens 3/22 was obtained.

\subsection{Detection of the LP Genes}

Genomic DNA from Bacillus amyloliquefaciens 3/22 was isolated using a High Pure PCR Template Preparation Kit (ROCHE, Indianopolis, IN, USA). PCR amplifications were carried out in $20 \mu \mathrm{L}$ reaction mixtures containing $7 \mu \mathrm{L}$ of nuclease-free water, $10 \mu \mathrm{L}$ of Thermo Scientific DreamTaq Green PCR Master Mix $(2 \times), 1 \mu \mathrm{L}$ of each $10 \mu \mathrm{M}$ primer and 
$1 \mu \mathrm{L}$ of bacterial DNA (10 $\mathrm{ng} / \mu \mathrm{L})$ isolated by the kit. PCR amplifications were performed using a GenePro (BIOER, Hangzhou, China) thermocycler. The following parameters were used: initial activation at $95{ }^{\circ} \mathrm{C}$ for $3 \mathrm{~min}$; 35 cycles of denaturation at $94{ }^{\circ} \mathrm{C}$ for $1 \mathrm{~min}$; annealing for $30 \mathrm{~s}$ at variable temperatures depending on the primers used; and an extension step at $70{ }^{\circ} \mathrm{C}$ for different times (due to the size of the primers used). Finally, the amplification was completed by the extension step at $70{ }^{\circ} \mathrm{C}$ for $10 \mathrm{~min}$. The reference surfactin-producing strain B. subtilis subsp. subtilis DSM 3257 was used as a positive control. The experiment included a negative control mixture without added DNA. The final product of the amplification reaction was analyzed by electrophoresis using a $1.5 \%$ agarose gel with $2 \mu \mathrm{L}$ GoodView ${ }^{\mathrm{TM}}$ (Ecoli) and evaluated by UV light visualization. The primers of genes used in the PCR amplification were selected based on the published data (Table 3). The products obtained from the PCRs were purified and sequenced using primers from both directions (Microsynth AG Postfach 586961 Wolfurt-Bahnhof Austria). The final sequences were compared with other bacterial sequences of the genes coding for biosynthesis of BSs in the National Center for Biotechnology Information (NCBI) database using BLASTn analysis. The software Sequin (https:/ /www.ncbi.nlm.nih.gov/Sequin/, accessed on 27 July 2019) was used for sending the sequences of BSs to the GenBank database. The GenBank accession numbers of BSs genes were obtained.

Table 3. The primers used to screen the genes responsible for BSs biosynthesis $[30,77,78]$.

\begin{tabular}{|c|c|c|c|c|}
\hline Biosurfactants & Gene & Sequence & PCR Product Size [bp] & $\begin{array}{c}\text { Annealing } \\
\text { Temperature }\left[{ }^{\circ} \mathrm{C}\right]\end{array}$ \\
\hline Surfactin & $s f p$ & $\begin{array}{l}\text { F-5'ATGAAGATTTACGGAATTTA } 3^{\prime} \\
\text { R-5'TTATAAAAGCTCTTCGTACG 3' }\end{array}$ & 675 & 50 \\
\hline \multirow{3}{*}{ Fengycin } & $\operatorname{srf} A A$ & $\begin{array}{c}\text { F-5'TCGGGACAGGAAGACATCAT 3' } \\
\text { R-5'CCACTCAAACGGATAATCCTGA } 3^{\prime}\end{array}$ & 201 & 60 \\
\hline & $f e n B$ & $\begin{array}{c}\text { F-5'CCTGGAGAAAGAATATACCGTACCY } 3^{\prime} \\
\text { R-5'GCTGGTTCAGTT KGATCACAT } 3^{\prime}\end{array}$ & 670 & 57 \\
\hline & fenD & $\begin{array}{c}\text { F-5'GGCCCGTTCTCTAAATCCAT } 3^{\prime} \\
\text { F-5'GTCATGCTGACGAGAGCAAA } 3^{\prime}\end{array}$ & 269 & 60 \\
\hline Iturin A & $i t u D$ & $\begin{array}{l}\text { F-5' TTGAAYGTCAGYGCSCCTTT } 3^{\prime} \\
\text { R-5' TGCGMAAATAATGGSGTCGT } 3^{\prime}\end{array}$ & 482 & 57 \\
\hline
\end{tabular}

\subsection{Isolation of Biosurfactants}

BSs were extracted using the method by Plaza et al. [30] with slight modifications. Briefly, $300 \mathrm{~mL}$ aliquot of McKeen medium was inoculated with 3\% (v/v) Bacillus amyloliquefaciens 3/22 and incubated in a rotary shaker (Shaker SKO-D XL, ARGOlab, Carpi, Italy) at $27^{\circ} \mathrm{C}$ with shaking $(140 \mathrm{rpm})$ for $72 \mathrm{~h}$. The bacterial culture was made cell free by centrifugation at $4800 \times g$ for $65 \mathrm{~min}$; the collected filtrate was acidified by $6 \mathrm{M} \mathrm{HCl}$ to $\mathrm{pH}$ 2. The precipitate that formed overnight at $4{ }^{\circ} \mathrm{C}$ was centrifuged again. The sediment was dissolved in $100 \mathrm{~mL}$ of distilled water and the $\mathrm{pH}$ of the solution was adjusted by $1 \mathrm{M}$ $\mathrm{NaOH}$ to a value of 7 . The LPs were extracted with ethyl acetate and methanol at a ratio of $4: 1(v / v)$. After combination, the organic layers were dried by sodium sulphate. The filtered solvent was concentrated in a rotary evaporator (IKA RV 10 Digital, IKA Germany) and the LPs (yellow oily product) were lyophilized and then stored at $-70^{\circ} \mathrm{C}$.

\subsection{Ultrahigh-Performance Liquid Chromatography}

The extracted and purified mixtures of lipopeptides were dissolved in acetonitrile and then filtered using a $0.22 \mu \mathrm{m}$ membrane filter. For analyses, the UHPLC Dionex UltiMate 3000 system with DAD detector at a wavelength of $214 \mathrm{~nm}$ was used. For separations, the reverse-phase column YMC Meteoric Core C18 Bio $(150 \times 4.6 \mathrm{~mm})$ with a particle size of $2.7 \mu \mathrm{m}$ was utilized. The injection volumes were $20 \mu \mathrm{L}$. All the standard lipopeptides (iturin A, fengycin, surfactin) were purchased from Sigma Aldrich, Germany. The concentration of standards was $0.5 \mathrm{mg} / \mathrm{mL}$. The eluent A consisted of $0.025 \%$ TFA in 
acetonitrile and eluent B was $0.025 \%$ water solution of TFA. The separation strategy was optimalized using gradient elution and at the 0-5 min mark 100\% of eluent B was used with the flow rate of $0.5 \mathrm{~mL} / \mathrm{min}$; the linear gradient followed from 5 to $10 \mathrm{~min}$, using $0-10 \%$ of eluent $\mathrm{A}$ with the flow rate of $0.8 \mathrm{~mL} / \mathrm{min}$, and finally, from 10 to $75 \mathrm{~min}, 10-90 \%$ of eluent $\mathrm{A}$ with the flow rate of $1.5 \mathrm{~mL} / \mathrm{min}$ was performed.

\subsection{MALDI-TOF/MS Analysis}

Studied LPs were analyzed using matrix-assisted laser desorption/ionization timeof-flight (MALDI-ToF MS Biotyper, Bruker Daltonics, Germany) to determine molecular mass. An amount of $1 \mu \mathrm{L}$ of the sample was inserted to a target plate (Bruker Daltonics, Germany, MSP Target) and dried at room temperature. 2- $\alpha$-cyano-4-hydroxycinnamic acid, HCCA (Sigma, Saint Louis, MO, USA) was used as a matrix. For desorption and ionization, the UV laser at the wavelength of $337 \mathrm{~nm}$ at $20 \mathrm{kV}$ voltage was used. The mass spectra were obtained using the mass spectrometer Microflex LT including flexControl 3.0 software (Bruker Daltonics, Bremen, Germany). The values of $m / z$ were measured randomly by 100 laser shots in the range of 800-2000. FlexAnalysis 3.0 software (Bruker Daltonics, Bremen, Germany) was used for analyses. The peaks detection was performed using a Centroid detection algorithm with a signal-to-noise threshold of 1 , a relative intensity threshold of $0 \%$, a minimum threshold of 0 , and a peak width of $0.2 \mathrm{~m} / z$ [79].

\subsection{Determination of Growth Inhibition Activity of LPS 3/22 against S. aureus in Planktonic Cells}

MIC of LPs 3/22 against S. aureus CCM 4223 was determined using broth microdilution assay. Serial twofold dilutions of LPs 3/22 resulting in concentrations ranging from $0.058 \mathrm{mg} / \mathrm{mL}$ to $30 \mathrm{mg} / \mathrm{mL}$ were prepared in BHI broth in a 96-well plate $(100 \mu \mathrm{L}$ per well). A diluted bacterial suspension was added to each well to control the final concentration of $1 \times 10^{6} \mathrm{CFU} / \mathrm{mL}$. The wells with media only were used as negative controls. By contrast, wells containing no LPs 3/22 in media, but only inoculated bacteria, were used as positive controls. The plates were incubated for $24 \mathrm{~h}$ at $37^{\circ} \mathrm{C}$ and the lowest concentration with any visible bacterial growth were considered the MIC. The assay was performed in triplicate.

\subsection{Effect of LPS on Biofilm Formation}

A modified microplate assay version of the previously described method of O'Toole et al. [80] was used for assaying the biofilm formation. Concentrations of LPs from B. amyloliquefaciens $3 / 22$ that ranged from $15 \mathrm{mg} / \mathrm{mL}$ to $0.0015 \mathrm{mg} / \mathrm{mL}$ (tenfold dilution) were obtained in 96-well plates with $100 \mu \mathrm{L}$ of mBHI broth per well (Greiner ELISA 8 Well Strips, $350 \mu \mathrm{L}$, Flat Bottom, Medium Binding; Cruinn Diagnostics Ltd., Dublin, Ireland). Afterward, bacterial suspension $(100 \mu \mathrm{L})$ of S. aureus CCM 4223 (McFarland 0.5) was inoculated, and the plates were incubated for $24 \mathrm{~h}$ at $37^{\circ} \mathrm{C}$. We used $\mathrm{mBHI}$ with saline or $\mathrm{mBHI}$ with relevant concentrations of LPs $3 / 22$ as negative controls. The mBHI broth with an indicator strain without LPs $3 / 22$ served as a positive control. After incubation, the supernatant was aspirated from the wells. The biofilm formed in the well of the microtitre plate was gently washed 3 times with $200 \mu \mathrm{L}$ of phosphate-buffered saline (PBS, pH 7.4; containing $\left.8 \mathrm{~g} / \mathrm{L} \mathrm{NaCl}, 0.0002 \mathrm{~g} / \mathrm{L} \mathrm{KCl}, 1.15 \mathrm{~g} / \mathrm{L} \mathrm{Na}_{2} \mathrm{HPO}_{4}, 0.2 \mathrm{~g} / \mathrm{L} \mathrm{KH}_{2} \mathrm{PO}_{4}\right)$ and dried at $25{ }^{\circ} \mathrm{C}$ for $40 \mathrm{~min}$. The remaining attached bacteria were stained for $30 \mathrm{~min}$ at $25{ }^{\circ} \mathrm{C}$ with $200 \mu \mathrm{L}$ of $0.1 \%(\mathrm{~m} / \mathrm{v})$ crystal violet in an isopropanol-methanol-PBS solution $(1: 1: 18 \mathrm{v} / \mathrm{v})$. The dye solution was aspirated away, and the well was gently washed 3 times with $200 \mathrm{~mL}$ of distilled water. After the water was removed and the cells were dried for $30 \mathrm{~min}$ at $25{ }^{\circ} \mathrm{C}$, the dye bound to the adhered biofilm was extracted with $200 \mu \mathrm{L}$ of $33 \%(v / v)$ glacial acetic acid in distilled water. A $150 \mu \mathrm{L}$ aliquot was transferred from each well to another microplate for determination of optical density (OD) at $550 \mathrm{~nm}$ using a Synergy 4 MultiMode Microplate Reader (BioTek, Winooski, VT, USA). The experiment was conducted in triplicate and the results are presented as the means \pm standard deviation (SD). Percentage inhibition of biofilm formation was calculated according to the formula (1) as described 
in the study of Jadhav et al. [81]. ABSs represent the absorbance of the well with the test strain and BSs and Ao absorbance of the well with the test strain without BSs.

$$
\text { Percentage inhibition }=[1-(\mathrm{ABSs} / \mathrm{Ao})] \times 100
$$

\subsection{Quantification of Gene Expression Using qRT-PCR}

LPs diluted in mBHI medium were inoculated with $0.5 \mathrm{McF}$ arland S. aureus CCM4223 into the concentrations of $1.5 \mathrm{mg} / \mathrm{mL}, 0.15 \mathrm{mg} / \mathrm{mL}$ and $0.015 \mathrm{mg} / \mathrm{mL}$ and subsequently incubated for $24 \mathrm{~h}$ at $37^{\circ} \mathrm{C}$. After washing with sterile PBS, the biofilm cells were collected by centrifugation $(5000 \times g$ for $10 \mathrm{~min})$ and stored at $-80^{\circ} \mathrm{C}$. Total RNA was isolated and purified by means of RiboPure ${ }^{\mathrm{TM}}$ Bacteria Kit (ThermoFisher SCIENTIFIC, Waltham, MA, USA) according to the manufacturer's instructions. To remove the residual DNA contaminating the purified RNA, the samples were treated with RNase-free DNase I. Integrity of RNA was verified by agarose gel electrophoresis. Its purity and concentration were determined by ND-8000 spectrophotometer (ThermoFisher SCIENTIFIC, Waltham, MA, USA). The isolated RNA ( $1 \mu \mathrm{g})$ was transcribed to cDNA by reverse transcription using Maxima H Minus Reverse Transcriptase (ThermoFisher SCIENTIFIC, Waltham, MA, USA) and Random Hexamer primers. The degree of relative expression of $S$. aureus genes (biofilmrelated genes) involved in formation of biofilm $f n b A, f n b B$ (cell wall associated (CWA) genes of proteins, microbial surface components recognizing adhesive matrix molecules (MSCRAMMs) adhesin proteins), srtA (transpeptidase catalysing the covalent adhesion of CWA proteins to cell wall peptidoglycans), operon icaADBC (polysaccharide intercellular adhesins) and agrA (quorum-sensing gene) was determined by qRT-PCR. Amplification and detection of specific products was conducted in triplicate by a CFX 96 RT system (Bio-Rad, Hercules, CA, USA) and Luna ${ }^{\circledR}$ Universal qPCR Master Mix (New England BioLabs, Ipswich, MA, USA) using thermal profiles and mixed components of reaction mixture according to the provided manual. Each reaction mixture contained $20 \mathrm{ng}$ cDNA and primers used in the final concentration of $0.5 \mathrm{pM}$. Sequences of gene-specific primers and the reference gene encoding B gyrase subunit $(\mathrm{g} y \mathrm{r} B)$, serving as an internal control for determination of gene expression level, are presented in Table 4. Some primers used in this study were designed by means of Primer3 software, according to selected sequences obtained from the GenBank database. A dissociation curve was constructed at the end of each reaction using the melting temperature from $50{ }^{\circ} \mathrm{C}$ to $95^{\circ} \mathrm{C}$ and reading at $0.5^{\circ} \mathrm{C}$ increments. For each qRT-PCR there were negative controls used without an added template. The relative mRNA levels of genes were determined by normalization of the value of $\mathrm{Cq}$ of the studied genes to the mean value of $\mathrm{Cq}$ of reference genes by means of analysis of the value $2^{-\Delta \mathrm{Cq}}$. The qRT-PCR data were expressed as the fold change in the levels of expression of genes in S. aureus CCM4223 cells exposed to various concentrations of LPs in comparison with the level of expression of control cells cultivated without LPs (calibrators).

\subsection{Statistical Analysis}

The data were analyzed by GraphPad Prism 6.01 software (GraphPad Inc., San Diego, CA, USA). The results were evaluated by one-way analysis of variance (ANOVA) followed by a Dunnett test with $p<0.05$ considered significant. 
Table 4. Primers used in the study of gene expression in S. aureus CCM4223.

\begin{tabular}{|c|c|c|c|}
\hline Gene & Primer & Primer Sequence $\left(5^{\prime}-3^{\prime}\right)$ & Reference \\
\hline \multirow{2}{*}{$f n b A$} & fnbA-F & GAAGTGGCACAGCCAAGAAC & This study \\
\hline & fnbA-R & ACGTTGACCAGCATGTGG & \\
\hline \multirow{2}{*}{$f n b B$} & fnbB-F & CAATGATCCTATCATTGAGAAGAGTG & This study \\
\hline & fnbB-R & ССТTСТАСАССТTСAACAGCTGTA & \\
\hline \multirow{2}{*}{$\operatorname{srt} A$} & srtA-F & GTGGTACTTATCCTAGTGGCAGC & This study \\
\hline & srtA-R & GCCTGCCACTTTCGATTTATC & \\
\hline \multirow{2}{*}{$i c a A$} & icaA-F & CTTGCTGGCGCAGTCAATAC & [82] \\
\hline & icaA-R & GTAGCCAACGTCGACAACTG & \\
\hline \multirow{2}{*}{$i c a D$} & icaD-F & ACCCAACGCTAAAATCATCG & [83] \\
\hline & icaD-R & GCGAAAATGCCCATAGTTTC & \\
\hline \multirow{2}{*}{$i c a B$} & icaB-F & ATACCGGCGACTGGGTTTAT & {$[83]$} \\
\hline & icaB-R & ATGCAAATCGTGGGTATGTGT & \\
\hline \multirow{2}{*}{$i c a C$} & icaC-F & CTTGGGTATTTGCACGCATT & [83] \\
\hline & icaC-R & GCAATATCATGCCGACACCT & \\
\hline \multirow{2}{*}{$\operatorname{agr} A$} & $\operatorname{agrA-F}$ & TCGTAAGCATGACCCAGTTG & This study \\
\hline & agrA-R & AAATCCATCGCTGCAACTTT & \\
\hline \multirow{2}{*}{ gyr $B$} & gyrB-F & CCAGGTAAATTAGCCGATTGC & [84] \\
\hline & gyrB-R & ATCGCCTGCGTTCTAGAGTC & \\
\hline
\end{tabular}

\section{Conclusions}

In conclusion, our study demonstrated that the antibiofilm effect of LPs (the mixture of surfactin, fengycin and iturin) from $B$. amyloliquefaciens $3 / 22$ was the result of a decrease in the down-regulation of $f n b A, f n b B$, sortase $A$ and ica $A D B C$ operon genes expression in S. aureus CCM 4223 biofilm. Our results indicate the potential of LPs use in the prevention of biofilm-related infections. However, the detailed molecular mechanism of action of purified compounds LPs $3 / 22$ must be investigated.

Author Contributions: Conceptualization, R.N. and K.E.; methodology, K.E., M.M., J.K., Z.B., K.R. and V.H.; software, R.M. and M.M.; validation, R.N., J.K. and V.H.; formal analysis, K.E.; investigation, E.S., J.K. and K.R.; resources, R.N. and M.M.; data curation, R.N., Z.B. and J.K.; writing-original draft preparation, R.N., Z.B. and K.E.; writing-review and editing, R.N., Z.B. and K.E.; visualization, J.K. and Z.B.; supervision, R.N.; project administration, R.N., E.S. and M.M.; funding acquisition, R.N., E.S. and M.M. All authors have read and agreed to the published version of the manuscript.

Funding: This publication was supported by the Slovak Research and Development Agency under the contract no. APVV-15-0377 and APVV-16-0203 and the Scientific Grand Agency of Ministry of Education of the Slovak Republic, grant number VEGA 1/0788/19.

Data Availability Statement: The data presented in this study are available in this study.

Acknowledgments: The authors would like to thank Miroslava Kačániová for her help with MALDITOF/MS measurements.

Conflicts of Interest: The authors declare no conflict of interest.

\section{References}

1. Sharma, D.; Misba, L.; Khan, A.U. Antibiotics versus biofilm: An emerging battleground in microbial communities. Antimicrob. Resist. Infect. Control 2019, 8, 76. [CrossRef]

2. Khan, J.; Tarar, S.M.; Gul, I.; Nawaz, U.; Arshad, M. Challenges of antibiotic resistance biofilms and potential combating strategies: A review. 3 Biotech 2021, 11, 169. [CrossRef]

3. Tong, S.Y.C.; Davis, J.S.; Eichenberger, E.; Holland, T.L.; Fowler, V.G. Staphylococcus aureus infections: Epidemiology, pathophysiology, clinical manifestations, and management. Clin. Microbiol. Rev. 2015, 28, 603-661. [CrossRef]

4. Sakr, A.; Brégeon, F.; Mège, J.L.; Rolain, J.M.; Blin, O. Staphylococcus aureus nasal colonization: An update on mechanisms, epidemiology, risk factors, and subsequent infections. Front. Microbiol. 2018, 9, 2419. [CrossRef]

5. Lister, J.L.; Horswill, A.R. Staphylococcus aureus biofilms: Recent developments in biofilm dispersal. Front. Cell. Infect. Microbiol. 2014, 4, 178. [CrossRef] [PubMed] 
6. Galié, S.; García-Gutiérrez, C.; Miguélez, E.M.; Villar, C.J.; Lombó, F. Biofilms in the food industry: Health aspects and control methods. Front. Microbiol. 2018, 9, 898. [CrossRef] [PubMed]

7. Czaplewski, L.; Bax, R.; Clokie, M.; Dawson, M.; Fairhead, H.; Fischetti, V.A.; Foster, S.; Gilmore, B.F.; Hancock, R.E.W.; Harper, D.; et al. Alternatives to antibiotics-a pipeline portfolio review. Lancet Infect. Dis. 2016, 16, 239-251. [CrossRef]

8. Cattior, V.; Felden, B. Future antibacterial strategies: From basic concepts to clinical challenges Vincent. J. Infect. Dis. 2019, 220, 350-360. [CrossRef]

9. Marchant, R.; Banat, I.M. Microbial biosurfactants: Challenges and opportunities for future exploitation. Trends Biotechnol. 2012, 30, 558-565. [CrossRef]

10. Hancock, R.E.W.; Alford, M.A.; Haney, E.F. Antibiofilm activity of host defence peptides: Complexity provides opportunities. Nat. Rev. Microbiol. 2021, 1-12. [CrossRef]

11. Li, W.; Separovic, F.; O'Brien-Simpson, N.M.; Wade, J.D. Chemically modified and conjugated antimicrobial peptides against superbugs. Chem. Soc. Rev. 2021, 50,4932-4973. [CrossRef]

12. Cappello, S.; Genovese, M.; Della Torre, C.; Crisari, A.; Hassanshahian, M.; Santisi, S.; Calogero, R.; Yakimov, M.M. Effect of bioemulsificant exopolysaccharide (EPS2003) on microbial community dynamics during assays of oil spill bioremediation: A microcosm study. Mar. Pollut. Bull. 2012, 64, 2820-2828. [CrossRef]

13. Balan, S.S.; Mani, P.; Kumar, C.G.; Jayalakshmi, S. Structural characterization and biological evaluation of Staphylosan (dimannooleate), a new glycolipid surfactant produced by a marine Staphylococcus saprophyticus SBPS-15. Enzyme Microb. Technol. 2019, 120, 1-7. [CrossRef] [PubMed]

14. Hentati, D.; Chebbi, A.; Hadrich, F.; Frikha, I.; Rabanal, F.; Sayadi, S.; Manresa, A.; Chamkha, M. Production, characterization and biotechnological potential of lipopeptide biosurfactants from a novel marine Bacillus stratosphericus strain FLU5. Ecotoxicol. Environ. Saf. 2019, 167, 441-449. [CrossRef] [PubMed]

15. Roy, A. A review on the biosurfactants: Properties, types and its applications. J. Fundam. Renew. Energy Appl. 2017, 8, 1-5. [CrossRef]

16. Vecino, X.; Cruz, J.M.; Moldes, A.B.; Rodrigues, L.R. Biosurfactants in cosmetic formulations: Trends and challenges. Crit. Rev. Biotechnol. 2017, 37, 911-923. [CrossRef]

17. Sachdev, D.P.; Cameotra, S.S. Biosurfactants in agriculture. Appl. Microbiol. Biotechnol. 2013, 97, 1005-1016. [CrossRef]

18. Nitschke, M.; Silva, S.S.E. Recent food applications of microbial surfactants. Crit. Rev. Food Sci. Nutr. 2018, 58, 631-638. [CrossRef]

19. Naughton, P.J.; Marchant, R.; Naughton, V.; Banat, I.M. Microbial biosurfactants: Current trends and applications in agricultural and biomedical industries. J. Appl. Microbiol. 2019, 127, 12-28. [CrossRef]

20. Narendrakumar, L.; Das, B.; Paramasivan, B.; Rasu, J.; Thomas, S. Quorum quenching and biofilm inhibition: Alternative imminent strategies to control the disease cholera. In Biotechnological Applications of Quorum Sensing Inhibitors; Springer: Berlin, Germany, 2018; pp. 63-85. [CrossRef]

21. Sarwar, A.; Brader, G.; Corretto, E.; Aleti, G.; Abaidullah, M.; Sessitsch, A.; Hafeez, F.Y. Qualitative analysis of biosurfactants from Bacillus species exhibiting antifungal activity. PLoS ONE 2018, 13, e0198107. [CrossRef]

22. Jacques, P. Surfactin and other lipopeptides from Bacillus spp. In Biosurfactants; Springer: Berlin, Germany, $2011 ;$ pp. 57-91.

23. Ongena, M.; Jacques, P. Bacillus lipopeptides: Versatile weapons for plant disease biocontrol. Trends Microbiol. 2008, 16, 115-125. [CrossRef]

24. Arima, K.; Kakinuma, A.; Tamura, G. Surfactin, a crystalline peptidelipid surfactant produced by Bacillus subtilis: Isolation, characterization and its inhibition of fibrin clot formation. Biochem. Biophys. Res. Commun. 1968, 31, 488-494. [CrossRef]

25. Kakinuma, A.; Sugino, H.; Isono, M.; Tamura, G.; Arima, K. Determination of fatty acid in surfactin and elucidation of the total structure of surfactin. Agric. Biol. Chem. 1969, 33, 973-976. [CrossRef]

26. Huszcza, E.; Burczyk, B. Surfactin isoforms from Bacillus coagulans. Z. Naturforsch. Sect. C J. Biosci. 2006, 61, 727-733. [CrossRef] [PubMed]

27. Wu, C.Y.; Chen, C.L.; Lee, Y.H.; Cheng, Y.C.; Wu, Y.C.; Shu, H.Y.; Gotz, F.; Liu, S.T. Nonribosomal synthesis of fengycin on an enzyme complex formed by fengycin synthetases. J. Biol. Chem. 2007, 282, 5608-5616. [CrossRef]

28. Meena, K.R.; Kanwar, S.S. Lipopeptides as the antifungal and antibacterial agents: Applications in food safety and therapeutics. Biomed Res. Int. 2015, 2015, 473050. [CrossRef]

29. Bedlovičová, Z.; Englerová, K.; Nemcová, R.; Kačániová, M. Identification of lipopeptides produced by Bacillus amyloliquefaciens strains. J. Microbiol. Biotechnol. Food Sci. 2021, 10, e3690. [CrossRef]

30. Plaza, G.; Chojniak, J.; Rudnicka, K.; Paraszkiewicz, K.; Bernat, P. Detection of biosurfactants in Bacillus species: Genes and products identification. J. Appl. Microbiol. 2015, 119, 1023-1034. [CrossRef]

31. Zhang, Q.X.; Zhang, Y.; Shan, H.H.; Tong, Y.H.; Chen, X.J.; Liu, F.Q. Isolation and identification of antifungal peptides from Bacillus amyloliquefaciens W10. Environ. Sci. Pollut. Res. 2017, 24, 25000-25009. [CrossRef] [PubMed]

32. Xu, B.H.; Ye, Z.W.; Zheng, Q.W.; Wei, T.; Lin, J.F.; Guo, L.Q. Isolation and characterization of cyclic lipopeptides with broadspectrum antimicrobial activity from Bacillus siamensis JFL15. 3 Biotech 2018, 8, 444. [CrossRef] [PubMed]

33. He, C.P.; Fan, L.Y.; Wu, W.H.; Liang, Y.Q.; Li, R.; Tang, W.; Zheng, X.L.; Xiao, Y.N.; Liu, Z.X.; Zheng, F.C. Identification of lipopeptides produced by Bacillus subtilis Czk1 isolated from the aerial roots of rubber trees. Genet. Mol. Res. 2017, 16, 1-13. [CrossRef] [PubMed]

34. Habe, H.; Taira, T.; Imura, T. Screening of a Bacillus subtilis strain producing multiple types of cyclic lipopeptides and evaluation of their surface-tension-lowering activities. J. Oleo Sci. 2017, 66, 785-790. [CrossRef] 
35. Mulligan, C.N.; Sharma, S.K.; Mudhoo, A. Biosurfactants: Research Trends and Applications; CRC Press: Boca Raton, FL, USA, 2019; ISBN 1466518243.

36. Ramyabharathi, S.; Sankari Meena, K.; Rajendran, L.; Karthikeyan, G.; Jonathan, E.I.; Raguchander, T. Biocontrol of wilt-nematode complex infecting gerbera by Bacillus subtilis under protected cultivation. Egypt. J. Biol. Pest Control 2018, 28, 21. [CrossRef]

37. Amruta, N.; Prasanna Kumar, M.K.; Puneeth, M.E.; Sarika, G.; Kandikattu, H.K.; Vishwanath, K.; Narayanaswamy, S. Exploring the potentiality of novel rhizospheric bacterial strains against the rice blast fungus Magnaporthe oryzae. Plant Pathol. J. 2018, 34 126-138. [CrossRef] [PubMed]

38. Perez, K.J.; Viana, J.d.S.; Lopes, F.C.; Pereira, J.Q.; dos Santos, D.M.; Oliveira, J.S.; Velho, R.V.; Crispim, S.M.; Nicoli, J.R.; Brandelli, A.; et al. Bacillus spp. isolated from puba as a source of biosurfactants and antimicrobial lipopeptides. Front. Microbiol. 2017, 8, 61. [CrossRef] [PubMed]

39. Gerayeli, N.; Baghaee-Ravari, S.; Tarighi, S. Evaluation of the antagonistic potential of Bacillus strains against Pectobacterium carotovorum subsp. carotovorum and their role in the induction of resistance to potato soft rot infection. Eur. J. Plant Pathol. 2018, 150, 1049-1063. [CrossRef]

40. Yang, H.; Li, X.; Li, X.; Yu, H.; Shen, Z. Identification of lipopeptide isoforms by MALDI-TOF-MS/MS based on the simultaneous purification of iturin, fengycin, and surfactin by RP-HPLC. Anal. Bioanal. Chem. 2015, 407, 2529-2542. [CrossRef]

41. Chen, X.; Zhang, Y.; Fu, X.; Li, Y.; Wang, Q. Isolation and characterization of Bacillus amyloliquefaciens PG12 for the biological control of apple ring rot. Postharvest Biol. Technol. 2016, 115, 113-121. [CrossRef]

42. Biniarz, P.; Łukaszewicz, M. Direct quantification of lipopeptide biosurfactants in biological samples via HPLC and UPLC-MS requires sample modification with an organic solvent. Appl. Microbiol. Biotechnol. 2017, 101, 4747-4759. [CrossRef]

43. Mubarak, M.Q.E.; Hassan, A.R.; Hamid, A.A.; Khalil, S.; Isa, M.H.M. A simple and effective isocratic HPLC method for fast identification and quantification of surfactin. Sains Malays. 2015, 44, 115-120. [CrossRef]

44. Kim, P.I.; Ryu, J.; Kim, Y.H.; Chi, Y.T. Production of biosurfactant lipopeptides iturin A, fengycin, and surfactin A from Bacillus subtilis CMB32 for control of Colletotrichum gloeosporioides. J. Microbiol. Biotechnol. 2010, 20, 138-145. [CrossRef] [PubMed]

45. Bernat, P.; Paraszkiewicz, K.; Siewiera, P.; Moryl, M.; Płaza, G.; Chojniak, J. Lipid composition in a strain of Bacillus subtilis, a producer of iturin A lipopeptides that are active against uropathogenic bacteria. World J. Microbiol. Biotechnol. 2016, $32,157$. [CrossRef] [PubMed]

46. Banat, I.M.; Satpute, S.K.; Cameotra, S.S.; Patil, R.; Nyayanit, N.V. Cost effective technologies and renewable substrates for biosurfactants' production. Front. Microbiol. 2014, 5, 697. [CrossRef] [PubMed]

47. Horn, J.N.; Sengillo, J.D.; Lin, D.; Romo, T.D.; Grossfield, A. Characterization of a potent antimicrobial lipopeptide via coarsegrained molecular dynamics. Biochim. Biophys. Acta BBA Biomembr. 2012, 1818, 212-218. [CrossRef]

48. De Jesús Cortés-Sánchez, A.; Hernández-Sánchez, H.; Jaramillo-Flores, M.E. Biological activity of glycolipids produced by microorganisms: New trends and possible therapeutic alternatives. Microbiol. Res. 2013, 168, 22-32. [CrossRef] [PubMed]

49. Rodrigues, L.R.; Banat, I.M.; Van Der Mei, H.C.; Teixeira, J.A.; Oliveira, R. Interference in adhesion of bacteria and yeasts isolated from explanted voice prostheses to silicone rubber by rhamnolipid biosurfactants. J. Appl. Microbiol. 2006, 100, 470-480. [CrossRef] [PubMed]

50. Tahmourespour, A.; Salehi, R.; Kermanshahi, R.K. Lactobacillus acidophilus-derived biosurfactant effect on $g t f b$ and $g t f c$ expression level in Streptococcus mutans biofilm cells. Braz. J. Microbiol. 2011, 42, 330-339. [CrossRef]

51. Yan, X.; Gu, S.; Cui, X.; Shi, Y.; Wen, S.; Chen, H.; Ge, J. Antimicrobial, anti-adhesive and anti-biofilm potential of biosurfactants isolated from Pediococcus acidilactici and Lactobacillus plantarum against Staphylococcus aureus CMCC26003. Microb. Pathog. 2019, 127, 12-20. [CrossRef]

52. Idrees, M.; Sawant, S.; Karodia, N.; Rahman, A. Staphylococcus aureus biofilm: Morphology, genetics, pathogenesis and treatment strategies. Int. J. Environ. Res. Public Health 2021, 18, 7602. [CrossRef]

53. Giri, S.S.; Ryu, E.C.; Sukumaran, V.; Park, S.C. Antioxidant, antibacterial, and anti-adhesive activities of biosurfactants isolated from Bacillus strains. Microb. Pathog. 2019, 132, 66-72. [CrossRef]

54. Janek, T.; Łukaszewicz, M.; Krasowska, A. Antiadhesive activity of the biosurfactant pseudofactin II secreted by the Arctic bacterium Pseudomonas fluorescens BD5. BMC Microbiol. 2012, 12, 24. [CrossRef]

55. De Araujo, L.V.; Guimarães, C.R.; da Silva Marquita, R.L.; Santiago, V.M.J.; de Souza, M.P.; Nitschke, M.; Freire, D.M.G. Rhamnolipid and surfactin: Anti-adhesion/antibiofilm and antimicrobial effects. Food Control 2016, 63, 171-178. [CrossRef]

56. Rivardo, F.; Turner, R.J.; Allegrone, G.; Ceri, H.; Martinotti, M.G. Anti-adhesion activity of two biosurfactants produced by Bacillus spp. prevents biofilm formation of human bacterial pathogens. Appl. Microbiol. Biotechnol. 2009, 83, 541-553. [CrossRef] [PubMed]

57. Cordeiro, R.d.A.; Weslley Caracas Cedro, E.; Raquel Colares Andrade, A.; Serpa, R.; José de Jesus Evangelista, A.; Sales de Oliveira, J.; Santos Pereira, V.; Pereira Alencar, L.; Bruna Leite Mendes, P.; Cibelle Soares Farias, B.; et al. Inhibitory effect of a lipopeptide biosurfactant produced by Bacillus subtilis on planktonic and sessile cells of Trichosporon spp. Biofouling 2018, 34, 309-319. [CrossRef] [PubMed]

58. Quinn, G.A.; Maloy, A.P.; Banat, M.M.; Banat, I.M. A comparison of effects of broad-spectrum antibiotics and biosurfactants on established bacterial biofilms. Curr. Microbiol. 2013, 67, 614-623. [CrossRef] [PubMed] 
59. Abdollahi, S.; Tofighi, Z.; Babaee, T.; Shamsi, M.; Rahimzadeh, G.; Rezvanifar, H.; Saeidi, E.; Amiri, M.M.; Ashtiani, Y.S.; Samadi, N. Evaluation of anti-oxidant and anti-biofilm activities of biogenic surfactants derived from Bacillus amyloliquefaciens and Pseudomonas aeruginosa. Iran. J. Pharm. Res. 2020, 19, 115-126. [CrossRef] [PubMed]

60. Meena, K.R.; Sharma, A.; Kanwar, S.S. Antitumoral and antimicrobial activity of surfactin extracted from Bacillus subtilis KLP2015. Int. J. Pept. Res. Ther. 2020, 26, 423-433. [CrossRef]

61. Englerová, K.; Nemcová, R.; Bedlovičová, Z.; Styková, E. Antiadhesive, antibiofilm and dispersion activity of biosurfactants isolated from Bacillus amyloliquefaciens 3/22. Česká Slov. Farm. 2021, 70, 172-178, in press.

62. Heilmann, C. Adhesion mechanisms of staphylococci. In Bacterial Adhesion; Springer: Berlin, Geramny, $2011 ;$ pp. 105-123.

63. Soltani, E.; Farrokhi, E.; Zamanzad, B.; Abadi, M.S.S.; Deris, F.; Soltani, A.; Gholipour, A. Prevalence and distribution of adhesins and the expression of fibronectin-binding protein ( $F n b A$ and $F n b B)$ among Staphylococcus aureus isolates from Shahrekord Hospitals. BMC Res. Notes 2019, 12, 49. [CrossRef]

64. Tsompanidou, E.; Denham, E.L.; Sibbald, M.J.J.B.; Yang, X.-M.; Seinen, J.; Friedrich, A.W.; Buist, G.; van Dijl, J.M. The sortase A substrates FnbpA, FnbpB, ClfA and ClfB antagonize colony spreading of Staphylococcus aureus. PLoS ONE 2012, 7, e44646. [CrossRef]

65. Ouyang, P.; He, X.; Yuan, Z.-W.; Yin, Z.-Q.; Fu, H.; Lin, J.; He, C.; Liang, X.; Lv, C.; Shu, G.; et al. Erianin against Staphylococcus aureus infection via inhibiting sortase, A. Toxins 2018, 10, 385. [CrossRef]

66. Novais, J.S.; Carvalho, M.F.; Ramundo, M.S.; Beltrame, C.O.; Geraldo, R.B.; Jordão, A.K.; Ferreira, V.F.; Castro, H.C.; Figueiredo, A.M.S. Antibiofilm effects of N,O-acetals derived from 2-amino-1,4-naphthoquinone are associated with downregulation of important global virulence regulators in methicillin-resistant Staphylococcus aureus. Sci. Rep. 2020, 10, 19631. [CrossRef]

67. Thappeta, K.R.V.; Zhao, L.N.; Nge, C.E.; Crasta, S.; Leong, C.Y.; Ng, V.; Kanagasundaram, Y.; Fan, H.; Ng, S.B. In-silico identified new natural sortase a inhibitors disrupt S. aureus biofilm formation. Int. J. Mol. Sci. 2020, 21, 8601. [CrossRef]

68. Mirzaee, M.; Najar Peerayeh, S.; Ghasemian, A.-M. Detection of icaABCD genes and biofilm formation in clinical isolates of methicillin resistant Staphylococcus aureus. Iran. J. Pathol. 2014, 9, 257-262.

69. Melo, T.A.; Dos Santos, T.F.; De Almeida, M.E.; Junior, L.A.G.F.; Andrade, E.F.; Rezende, R.P.; Marques, L.M.; Romano, C.C. Inhibition of Staphylococcus aureus biofilm by Lactobacillus isolated from fine cocoa. BMC Microbiol. 2016, 16, 250. [CrossRef]

70. Ma, Y.; Xu, Y.; Yestrepsky, B.D.; Sorenson, R.J.; Chen, M.; Larsen, S.D.; Sun, H. Novel inhibitors of Staphylococcus aureus virulence gene expression and biofilm formation. PLoS ONE 2012, 7, e47255. [CrossRef]

71. Rajasree, K.; Fasim, A.; Gopal, B. Conformational features of the Staphylococcus aureus AgrA-promoter interactions rationalize quorum-sensing triggered gene expression. Biochem. Biophys. Rep. 2016, 6, 124-134. [CrossRef]

72. Liu, J.; Li, W.; Zhu, X.; Zhao, H.; Lu, Y.; Zhang, C.; Lu, Z. Surfactin effectively inhibits Staphylococcus aureus adhesion and biofilm formation on surfaces. Appl. Microbiol. Biotechnol. 2019, 103, 4565-4574. [CrossRef]

73. Cramton, S.E.; Gerke, C.; Schnell, N.F.; Nichols, W.W.; Götz, F. The intercellular adhesion (ICA) locus is present in Staphylococcus aureus and is required for biofilm formation. Infect. Immun. 1999, 67, 5427-5433. [CrossRef]

74. Techaoei, S.; Leelapornpisid, P.; Santiarwarn, D.; Lumyong, S.; Mai, C. Preliminary screening of biosurfactant-producing microorganisms isolated from hot. Development 2007, 7, 38-43.

75. Morikawa, M.; Yoshihiko, H.; Tadayuki, I. A study on the structure-function relationship of lipopeptide biosurfactants. Biochim. Biophys. Acta BBA Mol. Cell Biol. Lipids 2000, 1488, 211-218. [CrossRef]

76. Frank, J.A.; Reich, C.I.; Sharma, S.; Weisbaum, J.S.; Wilson, B.A.; Olsen, G.J. Critical evaluation of two primers commonly used for amplification of bacterial 16S rRNA genes. Appl. Environ. Microbiol. 2008, 74, 2461-2470. [CrossRef]

77. Hsieh, F.C.; Li, M.C.; Lin, T.C.; Kao, S.S. Rapid detection and characterization of surfactin-producing Bacillus subtilis and closely related species based on PCR. Curr. Microbiol. 2004, 49, 186-191. [CrossRef]

78. Mora, I.; Cabrefiga, J.; Montesinos, E. Antimicrobial peptide genes in Bacillus strains from plant environments. Int. Microbiol. 2011, 14, 213-223. [CrossRef]

79. Caprioli, R.M.; Farmer, T.B.; Gile, J. Molecular imaging of biological samples: Localization of peptides and proteins using MALDI-TOF MS. Anal. Chem. 1997, 69, 4751-4760. [CrossRef]

80. O’Toole, G.A.; Pratt, L.A.; Watnick, P.I.; Newman, D.K.; Weaver, V.B.; Kolter, R. Genetic approaches to study of biofilms. In Methods in Enzymology; Elsevier: Amsterdam, The Netherlands, 1999; Volume 310, pp. 91-109.

81. Jadhav, S.; Shah, R.; Bhave, M.; Palombo, E.A. Inhibitory activity of yarrow essential oil on Listeria planktonic cells and biofilms. Food Control 2013, 29, 125-130. [CrossRef]

82. Iqbal, Z.; Seleem, M.N.; Hussain, H.I.; Huang, L.; Hao, H.; Yuan, Z. Comparative virulence studies and transcriptome analysis of Staphylococcus aureus strains isolated from animals. Sci. Rep. 2016, 6, 35442. [CrossRef]

83. Nourbakhsh, F.; Namvar, A. Detection of genes involved in biofilm formation in Staphylococcus aureus isolates. GMS Hyg. Infect. Control 2016, 11, Doc07. [CrossRef]

84. Pereyra, E.A.L.; Picech, F.; Renna, M.S.; Baravalle, C.; Andreotti, C.S.; Russi, R.; Calvinho, L.F.; Diez, C.; Dallard, B.E. Detection of Staphylococcus aureus adhesion and biofilm-producing genes and their expression during internalization in bovine mammary epithelial cells. Vet. Microbiol. 2016, 183, 69-77. [CrossRef] 